\title{
Physicochemical and biological activities of polysaccharides from the waste residue of sea
}

\section{cucumber peptide production}

\author{
Ruicong Zhang ${ }^{1}$, Rui Liu ${ }^{1,2}$, Yongde Chen ${ }^{3}$, Tao W $\mathbf{u}^{1}$, Wenjie Sui ${ }^{1}$, Min Zhang ${ }^{1,4}$ \\ ${ }^{1}$ State Key Laboratory of Food Nutrition and Safety, Tianjin University of Science \& Technology, Tianjin, China; \\ ${ }^{2}$ Engineering Research Center of Food Biotechnology, Ministry of Education, Tianjin, China; ${ }^{3}$ Bestlife Biological Technology \\ Co., Ltd., Hebei Province, China; ${ }^{4}$ Tianjin Agricultural University, Tianjin, China
}

"Corresponding Authors: Min Zhang, State Key Laboratory of Food Nutrition and Safety, Tianjin University of Science \& Technology, Tianjin, 300457, China; Tianjin Agricultural University, Tianjin, 300384, China. Tel.: +86-22-60912343. Fax: 86-22-60912343. Email: zm0102@sina.com; unwen_zm@163.com

Received: 26 March 2020 / Accepted: 28 August 2020 / Published: 08 October 2020 (c) 2020 Codon Publications

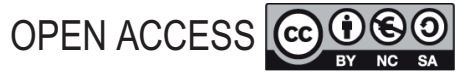

RESEARCH ARTICLE

\begin{abstract}
This study was to investigate the physicochemical and biological activities of sea cucumber polysaccharides extracted from waste residue of peptide production (SCRP). The monosaccharide composition of SCRP was 20.03\% mannose, $19.56 \%$ glucose, $18.63 \%$ galactose, $25.94 \%$ arabinose and $15.82 \%$ fucose with the $M_{\mathrm{w}}$ and $M_{\mathrm{n}}$ of SCRP of 57.5 and $51.3 \mathrm{kDa}$. The intrinsic viscosity of SCRP was $8.9 \mathrm{~mL} / \mathrm{mg}$ with a liquid-like rheological behaviour. Two main endothermic peak temperatures of the SCRP sample were 85.03 and $231.80^{\circ} \mathrm{C}$. SCRP rendered the early apoptosis of cells, as well as induced the loss of mitochondrial transmembrane potential and increase the reactive oxygen species (ROS) level with a concentration-dependence manner. The results implied that a by-product SCRP could be extracted from the waste residue during peptide production, and exhibited inhibitory effects against MDA-MB-231 cells.
\end{abstract}

Keywords: anti-tumour activities; sea cucumber peptide; sea cucumber polysaccharides; waste residue

\section{Introduction}

Sea cucumber is one of the most preferred marine foods with high economic and medicinal values. Due to its various biological components, such as polysaccharides, glycerophospholipids, saponins, collagens and so on, sea cucumber has become a nutritious product with essential physiological functions to human beings (Zhao et al., 2018). For example, sea cucumber polysaccharides showed activities of blood lipid-lowering, anti-tumour, anti-coagulation and enhance the immune functions (Janakiram et al., 2015). Collagen proteins and peptides from sea cucumber proven to be a potential bioactive substance, owning to their anti-hypertensive, blood pressure-lowering and anti-oxidative effects (Cui et al., 2007; Zhao et al., 2007; Zhou et al., 2012). A review of the literature summarised the health benefits of DHA/ EPA-enriched glycerophospholipids derived from dietary marine, showing that the glycerophospholipids from sea cucumber possess vital physiological activities of alleviating neurodegenerative disorders, anti-tumour, regulating lipid and glucose metabolism (Zhang et al., 2019). The marine cerebrosides also displayed strong bioactivity due to the special ocean circulation, although fewer classes and lower contents of cerebrosides are found in marine than living in the ground (Zhang et al., 2012). Sea cucumber-derived cerebrosides were reported to possess neuroprotective effects against $\mathrm{A} \beta_{1-42}$-triggered cognitive deficits (Li et al., 2019), and alleviate orotic acid-induced excess hepatic adipopexis in rats (Zhang et al., 2012), as well as own the protective effects of the oxidative damage in PC12 cells (Wuet al., 2013). The dietary saponins 
extracted from sea cucumber can improve specific obesity-related metabolic parameters and alleviate hepatic steatosis in rats (Hu et al., 2012).

Sea cucumber peptides produced by enzymatic hydrolysis have shown various potential biological activities, such as an angiotensin-converting enzyme, antioxidant and anti-proliferative activities (Lin et al., 2018; PérezVega et al., 2013). Nevertheless, the remaining residues containing polysaccharides and saponins became waste after extraction, enzymatic hydrolysis, and filtration of proteins and peptides. Sea cucumber polysaccharides are essential constituents of the sea cucumber wall, and have abundant biological activities including antioxidant, anti-tumour, anti-coagulant, anti-inflammatory, antithrombotic and anti-hyperlipidemic activities (Liu et al., 2012; Yang et al., 2019). Two novel sulphated polysaccharides have been isolated from sea cucumber body: fucosylated chondroitin sulphate and sulphated fucan (Albano and Mourão, 1986). In recent years, some researchers have isolated and purified polysaccharides from the sea cucumber by-products (Liu et al., 2016a; Yang et al., 2019). A homogeneous polysaccharide was purified from sea cucumber viscera and exhibited immune-enhancing activity (Yang et al., 2019). Besides, Apostichopus japonicus spawn polysaccharides were found to be able to inhibit tumour proliferation (Liu et al., 2016a). However, there is no report on the extraction and related active mechanisms of polysaccharides from the waste residues of sea cucumber peptide production (polysaccharides from sea cucumber waste residues, SCRP). Cancer is one of the whole world's leading causes of human loss (Vaikundamoorthy et al., 2018). Some studies showed that polysaccharides from sea cucumbers possess anti-tumour activity in vivo and in vitro (Lu and Wang, 2009; Ye et al., 2012). The acidic mucopolysaccharide from Holothuria leucospilota has shown antitumour effect by inhibiting angiogenesis and B16F10 tumour cell invasion in vivo and in vitro (Zhang et al., 2009). Stichopus japonicus acid mucopolysaccharide was reported to have a strong tumour-inhibiting effect on K563 leukaemia cells in vitro. However, it was also found that the crude extract of Stichopus japonicus, mainly containing polysaccharide, glycopeptide and glycoprotein, could render the proliferation of Bel-7402 liver cancer cells and C6 neuroglioma cells. The proliferation function might be attributed to the glycopeptide or glycoprotein if the anti-tumour effect of polysaccharide is certain (Zhang et al., 2009). Among all types of cancer, breast cancer is one of the most commonly diagnosed female cancers and is also a leading cause of cancer deaths in women aged 20 to 59 years (Siegel et al., 2016). The sulphated fucan from Vietnamese sea cucumber Stichopus variegatus was found to inhibit colony formation of human breast cancer cells T-47D and MDA-MB-231 and possess slight activity against the migration of
MDA-MB-231 cells (Thinh et al., 2018). However, the related mechanisms underneath were not elucidated. Till now, there are few researchers on the anticancer effects of sea cucumber polysaccharides on breast cancer, which needs to be further explored.

Apoptosis is a critical cell death mechanism regulated by a variety of complex signalling pathways (Sinha et al., 2013; Zhu et al., 2014). It is currently considered that oxidative stress, an excessive generation of reactive oxygen species (ROS), could induce cellular apoptosis via both intrinsic and extrinsic apoptotic pathways; both in the final stage resulted in the activation of caspases in mitochondria (Zhang et al., 2015a). Mitochondria dysfunction is an important indication in the apoptosis of cancer cells. The dysfunctional mitochondria converted into a diffused pattern and evenly distributed throughout the entire cytoplasm, thus could be indicated from changes of mitochondrial membrane potential using a fluorescent probe like JC-1 (Zhang et al., 2015b).

For the utilisation of the waste residue from sea cucumber peptide production, therefore, it was of interest to isolate the SCRP sample from the residue and to determine its physicochemical properties, as well as to investigate the effects of SCRP sample on human breast cancer cells MDA-MB-231. The determinations of physicochemical properties included molecular weight, monosaccharide composition, flow properties, and thermal stability. The cell viability was characterised by cell morphology, CCK-8 assay, flow cytometry and Hoechst33258 cell staining assay. The inhibitory effect of the SCRP sample on MDA-MB-31 cells was evaluated by the Rhodamine 123 cell staining assay, and the determination of ROS level and mitochondrial membrane potential.

\section{Materials and Methods}

\section{Materials}

The wet residue of sea cucumber (Apostichopus japonicus), obtained after proteolysis and separation of peptides, was provided by Bestlife Biological Technology Co., Ltd. (Hebei Province, China). Briefly, the sea cucumber wall was washed by water two times and ground in the beater at a speed of $100 \mathrm{r} / \mathrm{min}$ for $3 \mathrm{~min}$. After draining for $3 \mathrm{~min}$ and soaking for $60 \mathrm{~min}$, the broken sea cucumber wall was mixed with five-fold volume of the water and beaten at $300 \mathrm{r} / \mathrm{min}$ for $20 \mathrm{~min}$. The ground sea cucumber was hydrolysed by a compound enzyme (papain and trypsin at a ratio of $3: 1,800 \mathrm{U}$ ) at $35^{\circ} \mathrm{C}$ for $3 \mathrm{~h}$. Therefore, the wet sea cucumber residue was obtained, removing the peptide supernatant. Methanol and acetonitrile were purchased from Sigma Aldrich Chemical Co. (St. Louis, MO). Human metastatic breast 
cancer cell line MDA-MB-231 cells were obtained from Shanghai Jiao Tong University (China). All other reagents were purchased locally and were of analytical grade.

\section{Extraction of sea cucumber polysaccharides}

The wet sea cucumber residue was dried and ground in a conventional pulveriser to pass through a 90-mesh screen. Fifty grams of the residue powder was refluxed with $80 \%(\mathrm{v} / \mathrm{v})$ ethanol at $80^{\circ} \mathrm{C}$ three times, and then the precipitate was filtered and dried at $60^{\circ} \mathrm{C}$. Five grams of dried extracts were dissolved and refluxed in $40 \mathrm{~mL}$ sodium hydroxide solution $(2 \%, \mathrm{w} / \mathrm{v})$ at $95^{\circ} \mathrm{C}$ for $70 \mathrm{~min}$, and repeated five times, followed by condensation to $10 \%$ of the original volume in a RE-52AA type rotary evaporation instrument (Yarong Biochemical Instrument Factory, Shanghai, China). The concentrates were precipitated by adding four-fold the volume of $80 \%(\mathrm{v} / \mathrm{v})$ ethanol and kept overnight at $4{ }^{\circ} \mathrm{C}$. The mixture was centrifuged at $4000 \mathrm{rpm}$ for $20 \mathrm{~min}$ at $4^{\circ}$ and vacuum freezedried for $8 \mathrm{~h}$. The crude SCRP powder was obtained and further purified according to the method of Xiong et al. (2018). Five grams of crude SCRP powder was solubilised in $500 \mathrm{~mL}$ ultrapure water and filtered by a $0.45 \mu \mathrm{m}$ filter membrane. Then, an $8 \mathrm{~mL}$ crude sea cucumber polysaccharide sample was loaded on the DEAE-52 gel column (20 mm $\times 500$ mm, Sigma Corp., San Francisco, USA) for purification. The injection volume was $8 \mathrm{~mL}$ each time. Gradient elution was carried out with ultrapure water, $0.2 \mathrm{M}, 0.5 \mathrm{M}, 0.8 \mathrm{M}, 1.2 \mathrm{M}$ and $1.5 \mathrm{M} \mathrm{NaCl}$ solutions, and collected in a total of 20 tubes, $10 \mathrm{~mL}$ per tube. The total carbohydrate content was determined using the phenol-sulphuric acid method (Lin and Pomeranz, 1968). The elution curve of the crude SCRP sample was obtained by plotting the number of tubes as the abscissa, and the absorbance measured at $495 \mathrm{~nm}$ as the ordinate (Figure S1). As shown in Figure S1, the fraction of crude SCRP sample with the highest mass ratio of $53.8 \%$ was collected and named as SCRP.

\section{Physicochemical properties of SCRP}

\section{Molecular weight determination}

The molecular weight distribution of the SCRP sample was determined on a Shimadzu LC-20AT HPLC system (Shimadzu Corp., Tokyo, Japan) equipped with a RID10A refractive index detector (Shimadzu Corp., Tokyo, Japan) and a Shodex Ohpak SB-804HQ column $(8.0 \mathrm{~mm}$ $\times 300 \mathrm{~mm}, 10 \mu \mathrm{m}$, Showa Denko, Tokyo, Japan) placed in a $30^{\circ} \mathrm{C}$ column oven (Sun et al., 2018). The injection sample was $20 \mu \mathrm{L}$ of the SCRP solution $(10 \mathrm{mg} / \mathrm{mL})$. The elution phase was ultrapure water at a flow rate of $0.8 \mathrm{~mL} / \mathrm{min}$. Seven dextran standards (Nanjing Dichun Biotechnology Co., Ltd., Nanjing, China) with different molecular weights of 10,20,50,100,200, 400 and 600 $\mathrm{kDa}$ were used to calibrate the molecular weight curve.

\section{Determination of uronic acid and sulphate group content}

Uronic acid content was determined by the sulphamate/ 3-phenylphenol colourimetric method (Filisetticozzi and Carpita, 1991), using galacturonic acid $(10-60 \mu \mathrm{g} / \mathrm{mL})$ as standard. Sulphate group content was estimated by the barium chloride-gelatin method, as reported (Dodgson and Price, 1962).

\section{Monosaccharide composition}

The monosaccharide composition of the SCRP sample was determined by following the method of Yang et al. (2018) with some modifications. Briefly, $200 \mathrm{mg}$ SCRP powder was mixed with $10 \mathrm{~mL}$ of $2 \mathrm{M}$ trifluoroacetic acid (TFA) at $120^{\circ} \mathrm{C}$ for $2 \mathrm{~h}$. The mixture is centrifuged at $4000 \mathrm{rpm}$ for $20 \mathrm{~min}$ at $4^{\circ} \mathrm{C}$, and then the supernatant was evaporated to remove extra TFA at $60^{\circ} \mathrm{C}$ under vacuum pressure. The dried SCRP sample was dissolved with deionised water. One hundred microlitres of the SCRP sample solution was mixed with $100 \mu \mathrm{L}$ of $0.3 \mathrm{M}$ sodium hydroxide and $100 \mu \mathrm{L}$ of $0.5 \mathrm{M}$ 3-Methyl-1-phenyl-2-pyrazolin-5-one (PMP), incubating at $70^{\circ} \mathrm{C}$ for $60 \mathrm{~min}$. Then $100 \mu \mathrm{L}$ of 0.3 $\mathrm{M}$ hydrochloric acid was added to adjust the $\mathrm{pH}$ to 7 . One millilitre of dichloromethane was used to extract PMP three times. The monosaccharide standards (mannose, glucosamine hydrochloride, rhamnose, glucose, xylose, galactose, and arabinose) and the hydrolysed SCRP sample were dissolved in $1.5 \mathrm{~mL}$ deionised water for HPLC analysis. The HPLC determination was performed on an LC-20AT system (Shimadzu, Tokyo, Japan) equipped with an SPD-20A UV visible detector with UV absorbance of $230 \mathrm{~nm}$ and Thermo Fisher Acclaim 120 C18 column (250 $\mathrm{mm} \times 4.6 \mathrm{~mm}$ ). The flow rate was $1 \mathrm{~mL} / \mathrm{min}$ and the injection volume was $20 \mu \mathrm{L}$. Mobile phases A and B (v/v, 85:15) were ultrapure water and acetonitrile, respectively.

\section{Fourier transform infrared spectroscopy}

According to Liu et al. (2016b), Fourier transform infrared (FTIR) spectra were conducted on a Nicolet 6700 FTIR spectrometer (Thermo Fisher Scientific, Waltham, MA, USA). One milligram of the SCRP sample was mixed with $150 \mathrm{mg}$ potassium bromide powder and pressed into the disc for $30 \mathrm{~s}$ at $8 \mathrm{kN}$. Spectra were collected in the wavelength range of $400-4000 \mathrm{~cm}^{-1}$ over 32 scans at room temperature with a resolution of $1 \mathrm{~cm}^{-1}$.

\section{Flow properties}

\section{Intrinsic viscosity}

The viscosity of SCRP solutions $(0.3,0.5,0.8,1.0,1.2$ and $1.4 \mathrm{mg} / \mathrm{mL}$ ) was determined on a 0.57 Ukrainian-type capillary viscometer under the temperature of $30^{\circ} \mathrm{C}$. Using an accurate $15 \mathrm{~mL}$ of SCRP solution, the system 
was manually diluted after generating at least three efflux time readings at each concentration. The SCRP sample viscosity $(\eta)$ was converted to specific viscosity $\left(\eta_{\mathrm{sp}}\right)$ according to the following equation:

$$
\eta_{\mathrm{sp}}=\frac{\eta-\eta_{\mathrm{s}}}{\eta_{\mathrm{s}}}
$$

where, $\eta_{\mathrm{s}}$ represents the viscosity of the solvent (deionised water).

The intrinsic viscosity $[\eta]$ was usually obtained from extrapolation of $\eta_{\mathrm{sp}} / c$ to infinite dilution according to the Huggins empirical expression (Huggins, 1942) according to the following equation:

$$
\frac{\eta_{\mathrm{sp}}}{c}=[\eta]+k_{1}[\eta]^{2} c
$$

where, the Huggins coefficient $k_{1}$ represents a measure of polymer/polymer interaction in dilute conditions and also depends upon the extent of coil expansion of the polymer coil; $c$ represents the concentration of SCRP solution.

\section{Micro-rheology}

Three millilitres of SCRP solution with different concentrations of $3,3.75$ and $4.5 \mathrm{mg} / \mathrm{mL}$ was added to $4 \mathrm{~mL}$ sample cells and maintained at $30^{\circ} \mathrm{C}$. Microrheological curves were measured by Rheolaser Master (Formulaction, l'Union, France).

\section{Thermal stability}

The thermal stability was analysed by differential scanning calorimetry (DSC) on a DSC-60A plus calorimeter (Shimadzu Scientific Instruments Inc., Maryland, USA). Two milligrams SCRP sample was placed in an aluminium capsule and sealed. DSC thermogram was scanned from 30 to $300^{\circ} \mathrm{C}$ under the nitrogen atmosphere at a heating rate of $10^{\circ} \mathrm{C} / \mathrm{min}$.

\section{Cell viability on MDA-MB-231}

\section{Cell culture}

MDA-MB-231 cells were incubated in Leibovitz's L-15 medium containing $10 \%$ fetal bovine serum and $1 \%$ penicillin-streptomycin at $37^{\circ} \mathrm{C}$ in $95 \%$ air and $5 \% \mathrm{CO}_{2}$. The cells in the logarithmic growth phase were then collected and used for the following experiments.

\section{Cell morphology observation}

One hundred microlitres of MDA-MB-231 cells were seeded onto 96-well plates at a density of $5 \times 10^{4}$ cells/
$\mathrm{mL}$ and incubated at $37^{\circ} \mathrm{C}$ in $95 \%$ air and $5 \% \mathrm{CO}_{2}$ for $24 \mathrm{~h}$. Then, $10 \mu \mathrm{L}$ of SCRP solutions with different concentrations of 0 (Control), 50 (low concentration SCRP, LSCRP), 100 (middle concentration SCRP, MSCRP) and $200 \mu \mathrm{g} / \mathrm{mL}$ (high concentration SCRP, HSCRP) were added into 96-well plates and incubated for another 24 h. Cell morphology was observed on an inverted microscope $(\times 200)$.

\section{CCK-8 assay}

Hundred microlitres of cells in the logarithmic growth phase were plated at a density of $5 \times 10^{4}$ cells $/ \mathrm{mL}$ in 96-well plates and incubated for $24 \mathrm{~h}$. After the preincubation, cells were incubated with $10 \mu \mathrm{L}$ of SCRP solutions with various concentrations of $0,50,100$ and 200 $\mu \mathrm{g} / \mathrm{mL}$ for $24 \mathrm{~h}$, separately. Then, $10 \mu \mathrm{L}$ of CCK- 8 reagent was added to 96 -well plates and incubated at $37^{\circ} \mathrm{C}$ in $95 \%$ air and $5 \% \mathrm{CO}_{2}$ for $2 \mathrm{~h}$. The cell viability was calculated according to the following equation:

$$
\text { Cell viability rate }=\frac{O D_{\text {treatment }}-O D_{\text {blank }}}{O D_{\text {control }}-O D_{\text {blank }}} \times 100 \%
$$

\section{Flow cytometry}

Four microlitres of cell suspension at a density of $1 \times$ $10^{5}$ cells $/ \mathrm{mL}$ was inoculated into two culture flasks, followed by incubation at $37^{\circ} \mathrm{C}$ in $95 \%$ air and $5 \% \mathrm{CO}_{2}$ for $24 \mathrm{~h}$. Then, the cells were treated with $400 \mu \mathrm{L}$ of SCRP solutions with different concentrations of 0 , 50, 100 and $200 \mu \mathrm{g} / \mathrm{mL}$ for $24 \mathrm{~h}$. After trypsinisation, cells were washed twice with $1 \mathrm{~mL}$ of ice-cold PBS and suspended in $400 \mu \mathrm{L}$ of $1 \times$ Annexin $\mathrm{V}$ binding buffer. Five microlitres of Annexin V-FITC were added to the cell suspensions and incubated for $15 \mathrm{~min}$ in the dark, followed by the addition of $10 \mu \mathrm{L}$ of propidium iodide (PI) solution staining for $5 \mathrm{~min}$ in the dark (Huang et al., 2019). The samples were subjected to Millipore Guava easyCyte 8HT flow cytometer (Millipore, San Francisco, USA).

\section{Hoechst33258 cell staining assay}

MDA-MB-231 cells in the logarithmic growth phase were seeded into 6 -well plates at $5 \times 10^{5}$ cells/well and incubated at $37^{\circ} \mathrm{C}$ in $95 \%$ air and $5 \% \mathrm{CO}_{2}$ for $24 \mathrm{~h}$. Then, cells were treated with SCRP solutions with different concentrations of $0,50,100$ and $200 \mu \mathrm{g} / \mathrm{mL}$ for $24 \mathrm{~h}$. The cells were washed twice with fresh PBS and fixed with pre-cooled $75 \%$ ethanol for 2 min before staining with $200 \mu \mathrm{L}$ of Hoechst33258 staining solution $(1 \mathrm{mg} / \mathrm{mL})$ at $37^{\circ} \mathrm{C}$ for $25 \mathrm{~min}$. The nuclear staining was observed on an Olympus CKX41 fluorescence microscope (Olympus, Tokyo, Japan) with the excitation wavelength of $488 \mathrm{~nm}$, according to the method of Doynikova and Vekshin (2019). 


\section{Determination of mitochondrial transmembrane potential}

\section{Rhodamine 123 cell staining assay}

MDA-MB-231 cells were incubated with SCRP solutions with different concentrations of $0,50,100$ and $200 \mu \mathrm{g} /$ $\mathrm{mL}$ for $24 \mathrm{~h}$. The cells were washed once with fresh PBS and fixed with pre-cooled $75 \%$ ethanol for $2 \mathrm{~min}$. Then, $200 \mu \mathrm{L}$ of Rhodamine staining solution $(1 \mu \mathrm{g} / \mathrm{mL})$ was added into each well and incubated at $37^{\circ} \mathrm{C}$ for $25 \mathrm{~min}$. The images were captured using an Olympus CKX41 fluorescence microscope with an excitation wavelength of $495 \mathrm{~nm}$, according to the method of Pollard et al. (2019).

\section{JC-1 cell staining assay}

MDA-MB-231 cells in the logarithmic growth phase were seeded into 6 -well plates at $5 \times 10^{6}$ cells/well and incubated at $37^{\circ} \mathrm{C}$ in $95 \%$ air and $5 \% \mathrm{CO}_{2}$ for $24 \mathrm{~h}$. Then, cells were treated with SCRP solutions with different concentrations of $0,50,100$ and $200 \mu \mathrm{g} / \mathrm{mL}$ for $24 \mathrm{~h}$. After trypsinisation, cells were washed twice with $1 \mathrm{~mL}$ of ice-cold PBS and mixed with $1 \mathrm{~mL}$ of the medium and $1 \mathrm{~mL}$ of JC-1 (lipophilic cationic dye) working solution. The JC-1 working solution was prepared by adding $4 \mathrm{~mL}$ of distilled water into $1 \mathrm{~mL}$ of JC- 1 staining buffer $(5 \times)$ and kept in an ice bath. The cells were incubated at $37^{\circ}$ for $30 \mathrm{~min}$ and then washed twice with the JC-1 working solution. Flow cytometry was carried out on a Guava EasyCyte flow cytometer (Millipore, USA).

\section{Reactive oxygen species experiment}

MDA-MB-231 cells were prepared according to that described in the JC-1 cell staining assay. Then, cells were incubated with $10 \mu \mathrm{M}$ DCFH-DA (diluted 1000-fold by serum-free medium) at $37^{\circ} \mathrm{C}$ in $95 \%$ air and $5 \% \mathrm{CO}_{2}$ incubator for $0.5 \mathrm{~h}$ and then washed three times with PBS solution without serum to remove the extra DCFH-DA. Cellular ROS levels were quantified on a Guava EasyCyte flow cytometer (Millipore, USA) with the excitation wavelength and emission wavelength of $488 \mathrm{~nm}$ and 525 $\mathrm{nm}$, respectively.

\section{Statistical analysis}

Results were analysed by one-way ANOVA and Student's $\mathrm{t}$-test. Differences were considered to be statistically significant at $\mathrm{P}<0.05$ for all tests.

\section{Results and Discussion}

\section{Physicochemical properties of SCRP}

\section{Molecular weight distribution and chemical composition of SCRP}

The extraction yield of crude polysaccharides from the dried and ground sea cucumber was $4.29 \% \pm 0.14 \%$, and the yield of the SCRP sample after isolation by DEAE- 52 column was $2.31 \% \pm 0.08 \%$. The molecular weight and chemical composition of the SCRP sample are shown in Table 1, Figures S2 and S3. The average $M_{\mathrm{w}}$ and $M_{\mathrm{n}}$ of SCRP were 57.5 and $51.3 \mathrm{kDa}$, respectively, and the polydispersity index was 1.1. Furthermore, SCRP was composed of Man, Glc, Gal, Arab and Fuc with a molar ratio of 1.00:0.98:0.95:1.39:0.61, respectively. The uronic acid and sulphate group contents of the SCRP sample were 13.74 and $6.14 \%$, respectively. Liu et al. (2018) determined the monosaccharides of polysaccharides from fresh, dried, salty-dried, frozen-dried and dried sea cucumber samples, indicating sea cucumber polysaccharides contained different ratios of neutral sugars (Fuc, Arab, Gal and Man), amino sugars (GalN and GlcN) and uronic acid. Yang et al. (2019) isolated a homogeneous polysaccharide from the by-product sea cucumber viscera, mainly consisting of Man, GlcN, GlcUA, GalNAc, Glc, Gal and Fuc with a molar ratio of 1.00:1.41:0.88:2.14: $1.90: 1.12: 1.24$, respectively. The result was similar to that of a previous study in which polysaccharides were isolated from the body wall of sea cucumber Apostichopus japonicus (Liu et al., 2012). Nevertheless, our results of monosaccharide composition of the SCRP sample were different, probably because the sulphated fucan and fucosylated chondroitin sulphate were released to the proteolytic solution during the production of sea cucumber peptide.

\section{FTIR spectrum of SCRP}

The composition of the SCRP sample was further analysed by FTIR, as shown in Figure 1. The bands at 3400 and 2939 $\mathrm{cm}^{-1}$ were assigned to $\mathrm{O}-\mathrm{H}$ and $\mathrm{C}-\mathrm{H}$ stretching vibrations (Myron et al., 2017). The band at around $1653 \mathrm{~cm}^{-1}$ was due to the absorption of carboxylate anion of uronic acids, according to the report of Song et al. (2018). The absorption band at $1250 \mathrm{~cm}^{-1}$ was assigned to the stretching vibration of $\mathrm{S}=\mathrm{O}$ of sulphate (Yu et al., 2015). An additional unsymmetrical absorption band at $860 \mathrm{~cm}^{-1}$ represented $\mathrm{C}-\mathrm{O}-\mathrm{S}$ vibration, indicating that sulphate might occupy the positions in sugar residues (Ustyuzhanina et al., 2017).

Table 1. Molecular weight, chemical composition and viscosity of the SCRP sample.

\begin{tabular}{|c|c|c|c|c|c|c|c|c|c|c|}
\hline \multicolumn{3}{|c|}{ Molecular weight } & \multicolumn{7}{|c|}{ Chemical composition (\%) } & \multirow{2}{*}{$\begin{array}{l}\text { Viscosity } \\
\text { (mL/mg) }\end{array}$} \\
\hline$M_{\mathrm{w}}(\mathrm{kDa})$ & $M_{\mathrm{n}}(\mathrm{kDa})$ & $M_{\mathrm{w}} / M_{\mathrm{n}}$ & Man & GIc & Gal & Arab & Fuc & Uronic acid & Sulphate & \\
\hline $57.5 \pm 1.1$ & $51.3 \pm 1.0$ & $1.10 \pm 0.08$ & $20.03 \pm 0.19$ & $19.56 \pm 0.46$ & $18.63 \pm 0.25$ & $25.94 \pm 0.32$ & $15.82 \pm 0.43$ & $13.74 \pm 0.89$ & $6.14 \pm 0.13$ & $8.9 \pm 0.5$ \\
\hline
\end{tabular}




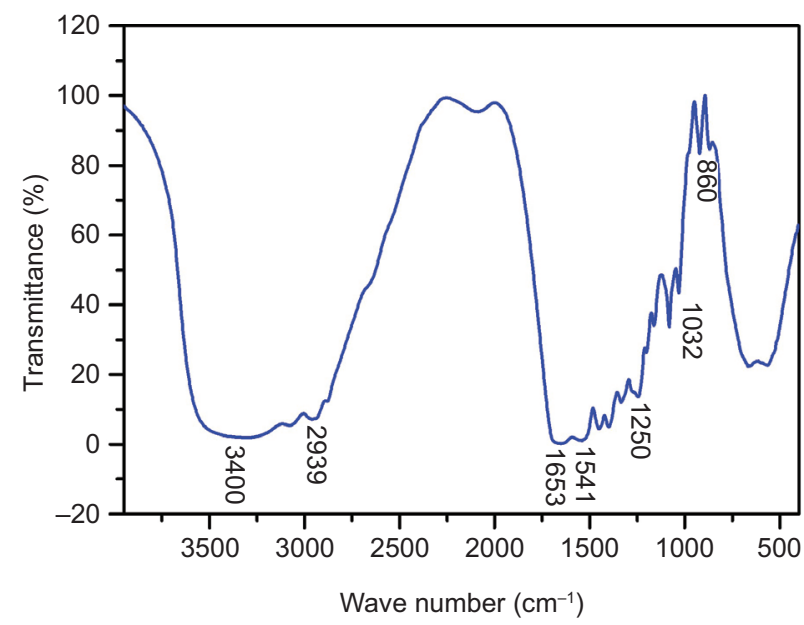

Figure 1. The FT-IR spectrum of sea cucumber polysaccharides (SCRP).

The FTIR results corresponded to the presence of uronic acid and sulphate group.

\section{Flow properties of SCRP}

\section{Intrinsic viscosity}

The intrinsic viscosity of SCRP, [ $\eta$ ], was determined using the Huggins empirical expression. The fitting plot was $\eta_{\mathrm{sp}} / c=-28.1 c+8.9\left(R^{2}=0.9616\right)$. The intrinsic viscosity of SCRP was $8.9 \mathrm{~mL} / \mathrm{mg}$, as shown in Table 1 . The moderate viscosity of the SCRP sample is beneficial to the application of SCRP in food processing.

\section{Flow behaviour}

The micro-rheological analysis was conducted to investigate the changes in the viscoelastic properties of SCRP along with time. Mean-square displacement (MSD) curves (Figure S4) of SCRP at different concentrations of $3,3.75$ and $4.5 \mathrm{mg} / \mathrm{mL}$ were analysed as a function of time. Figure $2 \mathrm{~A}$ shows the elasticity index (EI) value, which indicates the elasticity strength of the SCRP solution. The EI value of SCRP samples increased with increase in concentration, and each EI curve tended to be stable with increase in time. The decreasing trend of the EI curve as a function of time might be attributed to precipitation and flocculation at a relatively high concentration of the SCRP sample. The solid-liquid balance (SLB) value represents the MSD slope at short decorrelation time, which indicates the liquid or solid dominated rheological properties of SCRP samples with a key SLB value of 0.5 . The $0<$ SLB $<0.5$ indicates solid behaviour dominates, whereas $0.5<\mathrm{SLB}<1$ means liquid behaviour dominates. When the SLB $=0.5$, the liquid and solid parts are equally dominant (Yun et al., 2018). Figure 2B shows that SLB values of SCRP samples at concentrations of $3,3.75$ and $4.5 \mathrm{mg} / \mathrm{mL}$ were larger than 0.5 , indicating that liquid dominated the

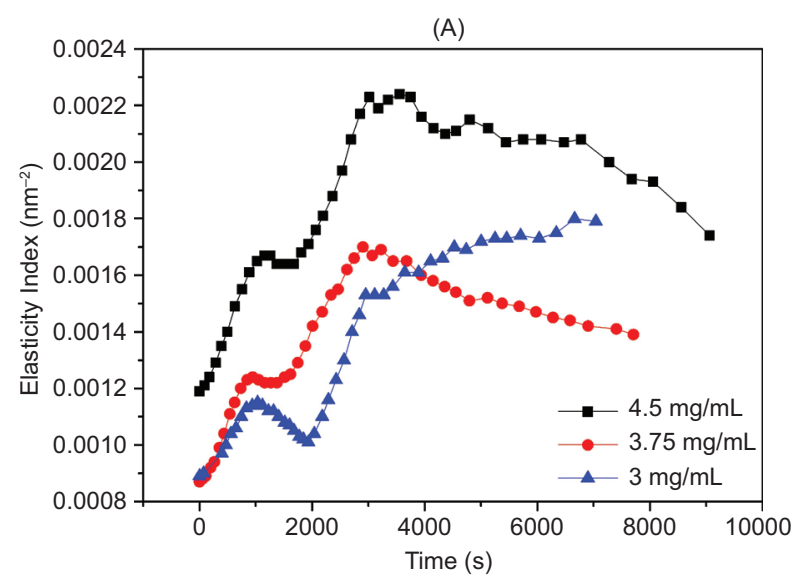

(B)

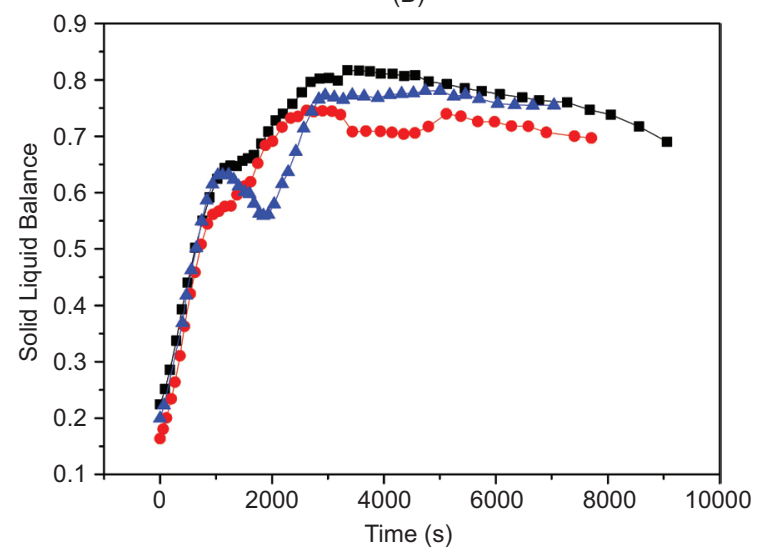

(C)

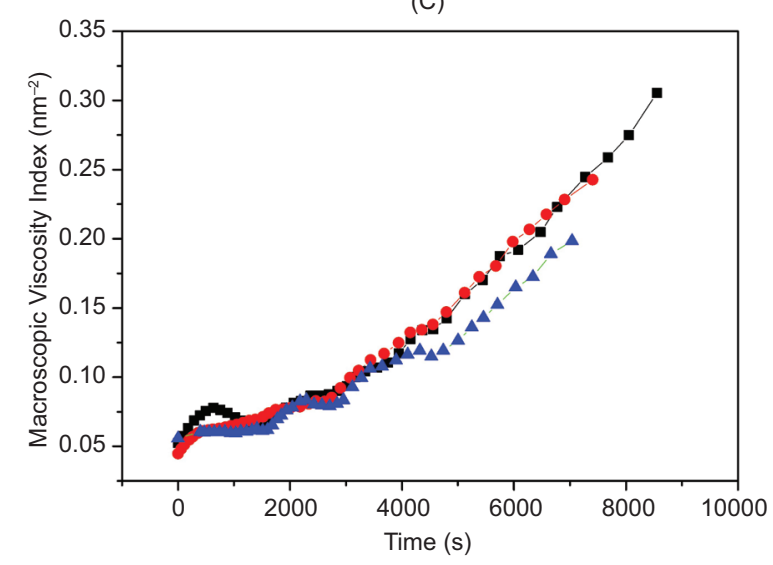

Figure 2. (A) Elastic index (EI), (B) solid-liquid balance (SLB) and (C) macroscopic viscosity index (MVI) curves of sea cucumber polysaccharides (SCRP) at different concentrations of $3,3.75$ and $4.5 \mathrm{mg} / \mathrm{mL}$.

solutions. The macroscopic viscosity index (MVI) value corresponds to the inverse slope of the MSD curve on a linear scale (Figure 2C) and represents the macroscopic viscosity without shear (Xu et al., 2016). SCRP samples at different concentrations had a similar slope, suggesting a liquid rheological behaviour of SCRP samples at concentrations of $3,3.75$ and $4.5 \mathrm{mg} / \mathrm{mL}$, and no significant influence of concentrations on the macroscopic viscosity. 


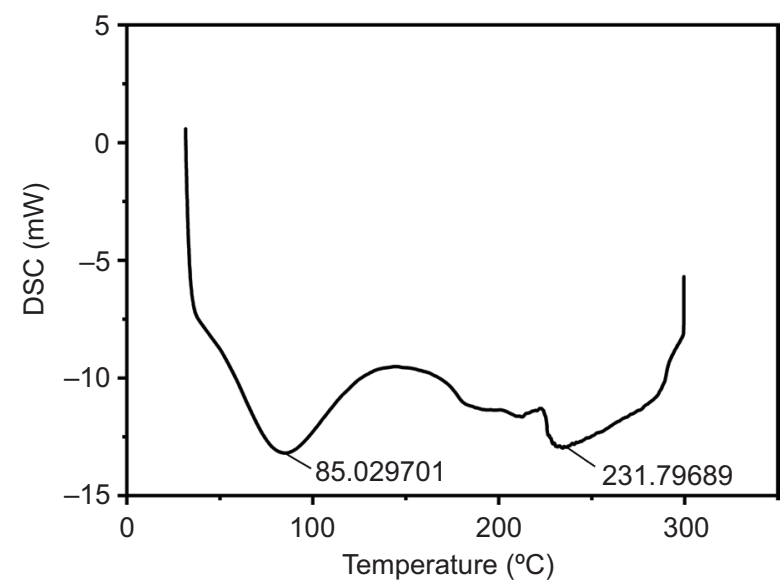

Figure 3. The differential scanning calorimetry (DSC) curve of sea cucumber polysaccharides (SCRP).

\section{Thermal properties of SCRP}

The melting of the SCRP sample was conducted with the temperature rising from $35^{\circ} \mathrm{C}$ to $300^{\circ} \mathrm{C}$ (Figure 3). Two main endothermic peaks appeared at 85.03 and $231.80^{\circ} \mathrm{C}$, which probably corresponded to the loss of water (Atabani et al., 2019) and decomposition of polysaccharides (Szeleszczuk et al., 2019), respectively.

\section{Cell viability on MDA-MB-231}

\section{Cell morphology}

The optical microscopic images of MDA-MB-231 cells are shown in Figure 4. In the control group, MDA-MB-231 cells appeared regular and shuttle-shaped with a smooth surface. A large number of MDA-MB-231 cells became rounded, shrunken or irregular shaped, and the number of adherence cells decreased with the treatment of 50 , 100 and $200 \mu \mathrm{g} / \mathrm{mL}$ SCRP samples. Cells were stripped away from walls and gathered into clusters, floating in the culture medium. The results indicated that SCRP could affect cell growth and lead to cell morphological change.

\section{Cell inhibition rate}

Table 2 showed the inhibition effect of SCRP extracted from waste residue of sea cucumber peptide production on MDA-MB-231 cells. SCRP samples at the concentrations of 50 and $100 \mu \mathrm{g} / \mathrm{mL}$ had slight inhibition effect on the cells by 3.88 and $15.12 \%$, respectively. While the SCRP sample at a concentration of $200 \mu \mathrm{g} / \mathrm{mL}$ exhibited a higher inhibition rate by $21.32 \%$. The antitumour activity of SCRP samples on breast cancer cells increased with the concentration increasing, indicating that SCRP suppresses cancer cell growth in a concentration-dependent manner (Tang et al., 2019).

Table 2. Effects of different concentrations of sea cucumber polysaccharides (SCRP) on growth inhibition activity in MDA-MB-231 cells.

\begin{tabular}{llc} 
Group & OD value & Inhibition rate (\%) \\
\hline Control & $0.258 \pm 0.027^{\mathrm{a}}$ & 0.00 \\
LSCRP & $0.248 \pm 0.002^{\mathrm{a}}$ & 3.88 \\
MSCRP & $0.219 \pm 0.009^{\mathrm{a}, \mathrm{b}}$ & 15.12 \\
HSCRP & $0.203 \pm 0.009^{\mathrm{b}}$ & 21.32 \\
\hline
\end{tabular}

$\mathrm{OD}$ values are expressed as mean \pm standard deviation Different letters indicated significant differences at $P<0.05$ in the same column.
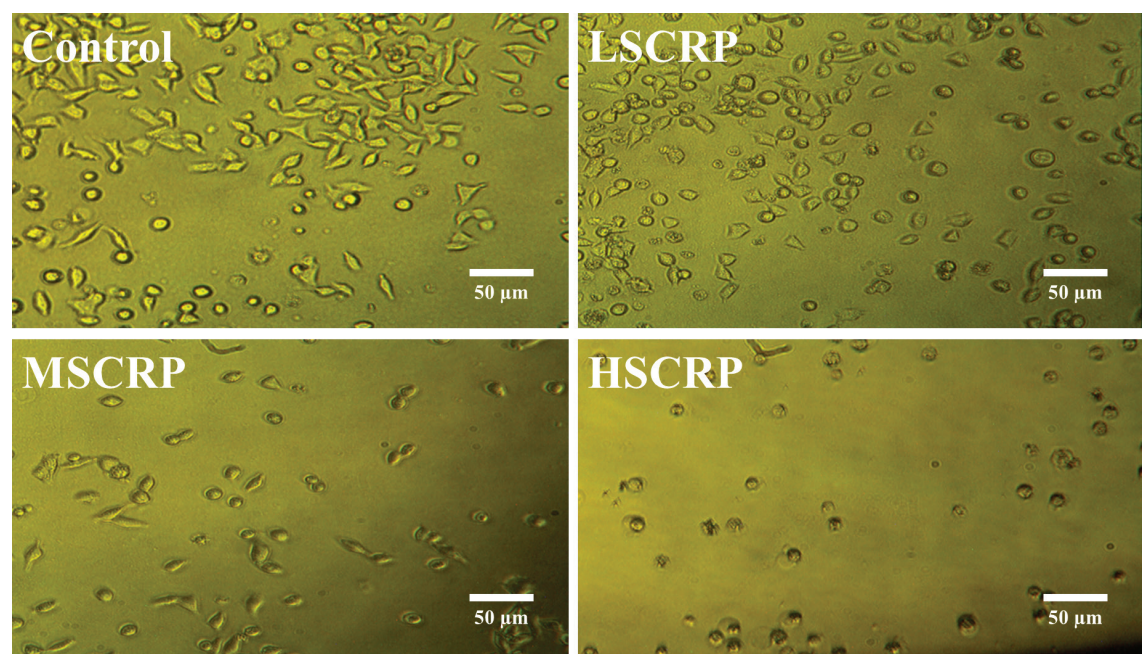

Figure 4. Inverted fluorescence microscopy results of MDA-MB-231 cells treated with different concentrations $(0,50,100$ and $200 \mu \mathrm{g} / \mathrm{mL}$ ) of sea cucumber polysaccharides (SCRP), designated as Control, LSCRP, MSCRP and HSCRP groups. 


\section{Cell apoptosis induction}

The apoptosis effect of SCRP was detected with the Annexin V-FITC/PI assay to determine whether SCRP exerted cytotoxicity effects on the MDA-MB-231 cells (Figure 5A). It could be seen that SCRP could significantly induce early apoptosis to the MDA cells. 4.25, 5.58 and $13.81 \%$ of cells were apoptotic by treating with 50 , 100 and $200 \mu \mathrm{g} / \mathrm{mL}$ of SCRP, respectively. HSCRP group exhibited the highest apoptosis effect on breast cancer cells with a notable difference in early and late apoptotic and necrosis rate, compared to the control group.

\section{Hoechst33258 cell staining assay}

Hoechst3358 is a dye that can stain the nucleus to identify apoptosis-related changes in the nucleus, such as chromatin concentration and fragmentation (Doynikova and Vekshin, 2019). When cells apoptosis, chromatin will shrink. Therefore, after Hoechst 33258 staining, it was observed under the fluorescence microscope that the cells in the control group were spindle-shaped, the nuclei with complete structure (Figure 5B) were normal blue. In contrast, the nuclei of apoptotic cells were dense and concentrated bright blue, or fragmented with some white colour, for example, in the MSCRP group and HSCRP group. Especially in the HSCRP group, MDA-MB-231 cells were severely damaged, with nuclear condensation and chromosomal defects.

\section{Determination of mitochondrial transmembrane potential}

\section{Rhodamine 123 cell staining assay}

The loss of mitochondrial transmembrane potential is an early sign of the apoptotic process. In order to determine if there is an early loss of mitochondrial transmembrane potential when different concentrations of SCRP samples were added, we conducted Rhodamine123 (Rh123) staining, JC-1 cell staining and ROS assays with the addition of SCRP on MDA-MB-231 cells. When external factors stimulate cells, it will cause a series of changes in mitochondria: the disappearance of mitochondrial membrane potential, the reduction of mitochondrial ATP production, the reduction of translation and transcription activities in mitochondria, thus, causing apoptosis and death of cells. Rh123 is a lipophilic cationic fluorescent dye, which has a permeability to the cell membrane and can be selectively enriched

(A)
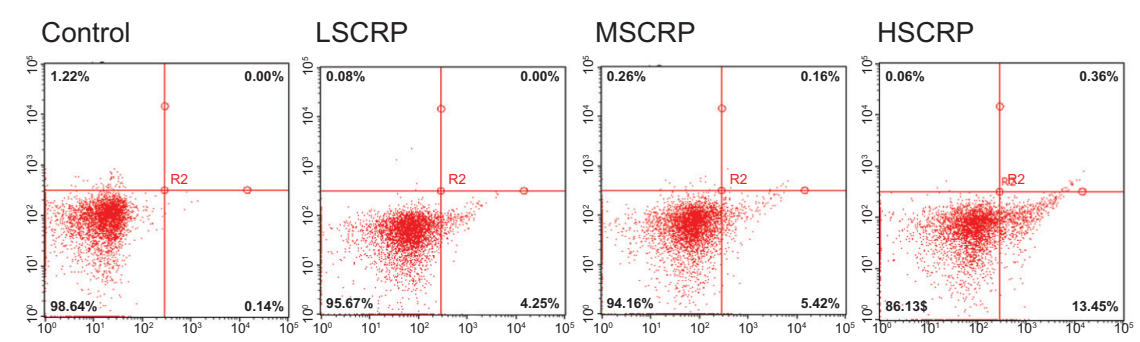

(B)
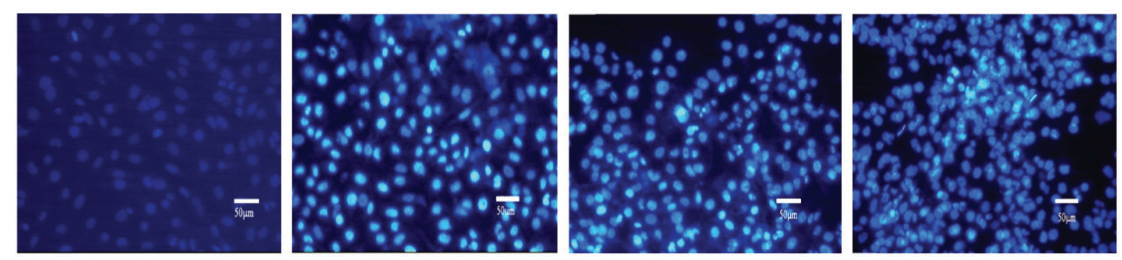

(C)
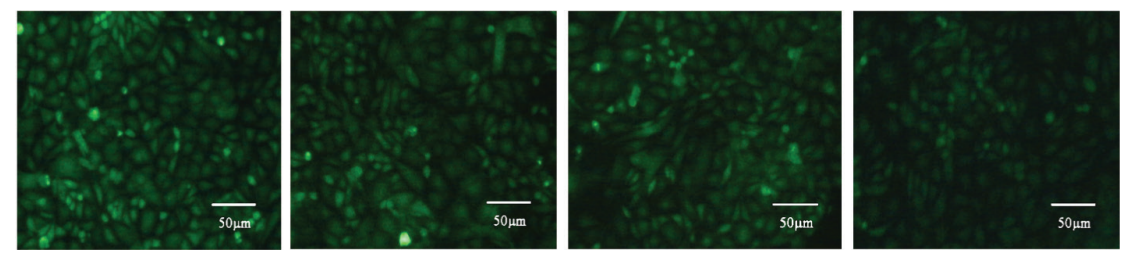

Figure 5. (A) Apoptotic flow diagram, (B) Hoechst33258 staining experiment and (C) Rhodamine 123 staining experiment results of MDA-MB-231 cells treated with different concentrations $(0,50,100$ and $200 \mu \mathrm{g} / \mathrm{mL})$ of sea cucumber polysaccharides (SCRP), designated as Control, LSCRP, MSCRP and HSCRP groups. 
in mitochondria. Figure $5 \mathrm{C}$ shows that most of the cells in the control group and LSCRP group are bright yellow-green; many of the cells in the MSCRP group and HSCRP group are obviously light green and dark green, and the fluorescence intensity decreased. The overall brightness of cells in the LSCRP group was higher than that in the MSCRP group and HSCRP group. When the cell is in the survival state, Rh123 accumulates in the mitochondria and emits green fluorescence through the cell membrane. During apoptosis, the mitochondrial membrane transport ability decreases, the electronegativity decreases, the ability of the mitochondria to accumulate Rh123 is also lost, and the fluorescence intensity decreases (Rajpurohit et al., 1999). The JC-1 experiment further demonstrated the decrease of mitochondrial transmembrane potential.

\section{JC-1 cell staining assay}

The uptake of JC-1 by mitochondria is dependent on transmembrane potential. JC-1 can easily enter cells through the plasma membrane and accumulates in the mitochondria (Mathur et al., 2000; Zhang et al., 2015b). The healthy MDA-MB-231 cells have a high mitochondrial membrane potential and show red fluorescence after staining ("active" mitochondria). If the mitochondrial membrane potential decreased, it would show a fluorescence transition from red to green after staining ("inactive" mitochondria). Figure 6A shows that with the increase in concentration, green fluorescence increases significantly, indicating the reduction of the mitochondrial membrane potential. The result agrees with rhodamine staining fluorescence. Therefore, by destroying the membrane potential, the internal and external

(A)
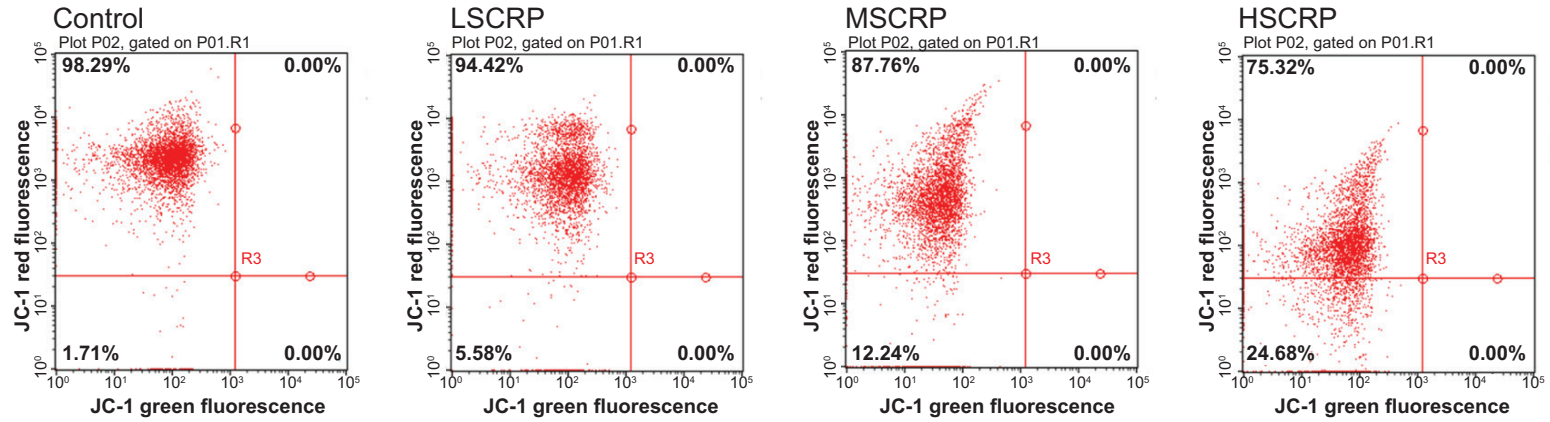

(B)
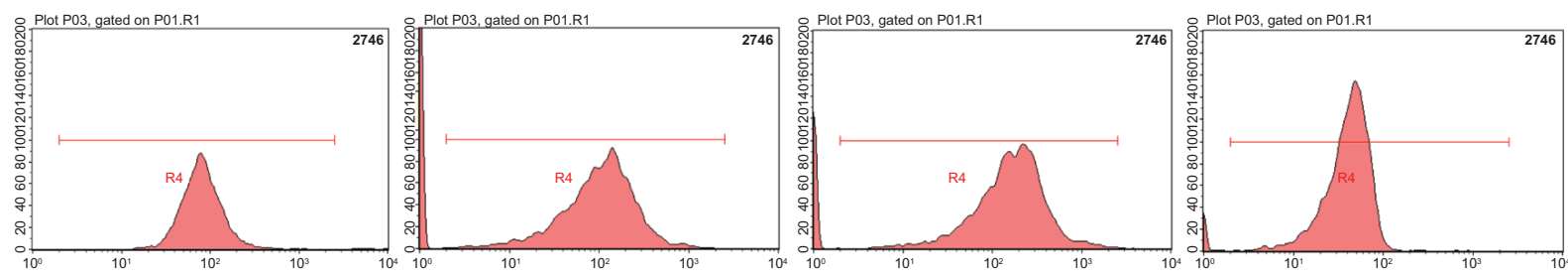

(C)

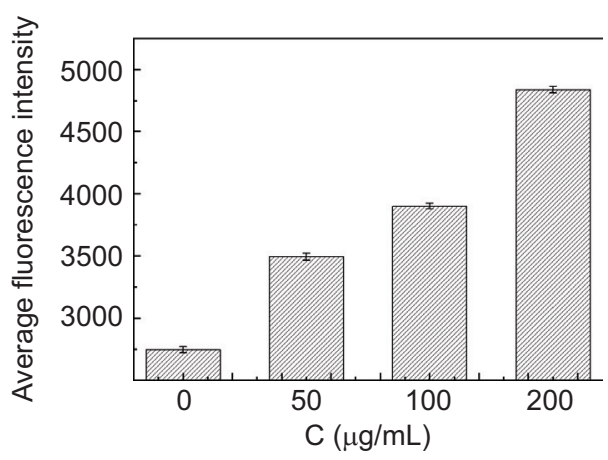

Figure 6. (A) FL1-FL2 scatter diagram of MDA-MB-231 cells stained by JC-1, (B) cell mitochondrial membrane potential changes of the MDA-MB-231 cells, (C) the ROS changes of the MDA-MB-231 cells after treatment with different concentrations $(0,50,100$ and $200 \mu \mathrm{g} / \mathrm{mL})$ of sea cucumber polysaccharides (SCRP), designated as Control, LSCRP, MSCRP and HSCRP groups. 
balance of the cell membrane is broken, so that the cell apoptosis occurs in the early stage, as proved by the previous apoptosis experiment, and the following ROS experiment.

\section{Reactive oxygen species experiment}

We assessed the ROS level in MDA-MB-231 cells treated with different concentrations of SCRP samples $(0,50,100$ and $200 \mu \mathrm{g} / \mathrm{mL}$ ) using a DCFH-DA probe. Compared to the control group, SCRP resulted in an increase of ROS generation in a concentration manner, with the fluorescence intensity gradually rising from $2746 \pm 54$ to $4838 \pm$ 48 (Figure 6B and C). Therefore, the preliminary work of this study proved that SCRP could inhibit MDA-MB-231 cell proliferation and induce apoptosis. The increasing trend of ROS generation concurred with the enhancement of growth inhibition activity of SCRP on MDA-MB-231 cells, and both the inhibition rate and ROS level increased with the SCRP concentration increasing.

The mitochondrion is the main production centre of intracellular ATP, which plays a crucial role in cell apoptosis and is also an essential place for ROS production (Shin et al., 2009). The mitochondrial membrane potential is affected by the asymmetric distribution of protons and other ions on both sides of the mitochondrial inner membrane. The opening of mitochondrial permeability transition pore (MPTP) will lead to the change of mitochondrial membrane permeability. When MPTP continues to open, the substances with high molecular weight can enter into the pore channel with no selectivity.

Meanwhile, mitochondria swell and outer membrane rupture, which leads to the decrease of mitochondrial membrane potential and cell apoptosis. Therefore, the low membrane potential is the characteristic sign of cell apoptosis (Chen et al., 2018). The rise of the ROS level, as a signal molecule, affects the cell signal transduction system, promotes further opening of the channel pores on the mitochondrial membrane, thereby reduces the mitochondrial membrane potential and induces the cascade reaction of apoptosis (Dar et al., 2019).

\section{Conclusion}

Polysaccharides from sea cucumber waste residues were separated and purified from the waste residue of sea cucumber peptide production. The physicochemical, flow properties, thermal property and biological activities of the SCRP sample were studied. The results indicated that SCRP consisted of $20.03 \%$ mannose, $19.56 \%$ glucose, $18.63 \%$ galactose, $25.94 \%$ arabinose and $15.82 \%$ fucose with the $M_{\mathrm{w}}$ and $M_{\mathrm{n}}$ of SCRP of 57.5 and $51.3 \mathrm{kDa}$, thereby possessing liquid-like rheological behaviour and thermal properties. SCRP rendered the early apoptosis of cells, as well as induced the loss of mitochondrial transmembrane potential and increase the ROS level. The polysaccharides extracted from waste residue of sea cucumber peptide production showed inhibitory effects against MDA-MB-231 cells.

\section{Funding}

The research was supported by the project of the Tianjin Education Commission (No. 2018KJ089).

\section{References}

Albano, R. and Mourão, P., 1986. Isolation, fractionation, and preliminary characterization of a novel class of sulfated glycans from the tunic of Styela plicata (Chordata Tunicata). Journal of Biological Chemistry 261: 758-765. PMID: 2867092

Atabani, A.E., Shobana, S., Mohammed, M.N., Uguz, G., Kumar, G., Arvindnarayan, S., Aslam, M. and Al-Muhtaseb, A.H., 2019. Integrated valorization of waste cooking oil and spent coffee grounds for biodiesel production: blending with higher alcohols, FT-IR, TGA, DSC and NMR characterizations. Fuel 244: 419430. https://doi.org/10.1016/j.fuel.2019.01.169

Chen, W., Zhao, Z., Li, L., Wu, B., Chen, S.F., Zhou, H., Wang, Y. and Li, Y.Q., 2018. Hispolon induces apoptosis in human gastric cancer cells through a ROS-mediated mitochondrial pathway. Free Radical Biology \& Medicine 45: 60-72. https://doi. org/10.1016/j.freeradbiomed.2008.03.013

Cui, F.X., Xue, C.H., Li, Z., Zhang, Y.Q., Dong, P., Fu, X.Y. and Gao, X., 2007. Characterization and subunit composition of collagen from the body wall of sea cucumber Stichopus japonicus. Food Chemistry 100: 1120-1125. https://doi.org/10.1016/j. foodchem.2005.11.019

Dar, P.A., Mir, S.A., Bhat, J.A., Hamid, A., Singh, L.R., Malik, F. and Dar, T.A., 2019. An anti-cancerous protein fraction from Withania somnifera induces ROS-dependent mitochondria-mediated apoptosis in human MDA-MB-231 breast cancer cells. International Journal of Biological Macromolecules 135: 77-87. https://doi.org/10.1016/j.ijbiomac.2019.05.120

Dodgson, K. and Price, R., 1962. A note on the determination of the ester sulphate content of sulphated polysaccharides. Biochemical Journal 84: 106-110. https://doi.org/10.1042/bj0840106

Doynikova, A.N. and Vekshin, N.L., 2019. Fluorescent determination of micro-quantities of RNA using Hoechst 33258 and binase. Analytical Biochemistry 576: 5-8. https://doi. org/10.1016/j.ab.2019.04.002

Filisetticozzi, T.M.C.C. and Carpita, N.C., 1991. Measurement of uronic acids without interference from neutral sugars. Analytical Biochemistry 197: 157-162. https://doi.org/10.1016/00032697(91)90372-Z

Hu, X.Q., Li, Z.J., Xue, Y., Xu, J., Xue, C.H., Wang, J.F. and Wang, Y.M., 2012. Dietary saponins of sea cucumber ameliorate obesity, hepatic steatosis, and glucose intolerance in high-fat 
diet-fed mice. Journal of Medicinal Food 15: 909-916. https:// doi.org/10.1089/jmf.2011.2042

Huang, W., Deng, H., Jin, S.Y., Yang, W.B., Wang, H.L., Meng, C.Q., Wang, H. and Yang, S.H., 2019. A polysaccharide from dried aerial parts of Agrimonia pilosa: structural characterization and its potential therapeutic activity for steroid-induced necrosis of the femoral head (SANFH). Carbohydrate Polymers 214: 71-79. https://doi.org/10.1016/j.carbpol.2019.03.004

Huggins, M., 1942. The viscosity of dilute solutions of long-chain molecules. IV. Dependence on concentration. Journal of the American Chemical Society 64: 2716-2718. https://doi. org/10.1021/ja01263a056

Janakiram, N., Mohammed, A. and Rao, C., 2015. Sea cucumbers metabolites as potent anti-cancer agents. Marine Drugs 13: 2909-2923. https://doi.org/10.3390/md13052909

Li, Q., Che, H.-X., Wang, C.-C., Zhang, L.-Y., Ding, L., Xue, C.-H., Zhang, T.-T. and Wang, Y.-M., 2019. Cerebrosides from sea cucumber improved A $\beta 1-42$-induced cognitive deficiency in a rat model of Alzheimer's disease. Molecular Nutrition \& Food Research 63: 1800707. https://doi.org/10.1002/mnfr.201800707

Lin, F. and Pomeranz, Y., 1968. Effect of borate on colorimetric determinations of carbohydrates by the phenol-sulfuric acid method. Analytical Biochemistry 24: 128-131. https://doi. org/10.1016/0003-2697(68)90067-5

Lin, L.Z., Kun, Y., Lin, Z., Ming, Z.M., Zheng, S.W., Yuan, Z.Q. and Jun, L.S., 2018. Anti-aging effect of sea cucumber (Cucumaria frondosa) hydrolysate on fruit flies and d-galactose-induced aging mice. Journal of Functional Foods 47: 11-18. https://doi. org/10.1016/j.jff.2018.05.033

Liu, X., Liu, J., Zhang, J., Wang, T., Wang, G., Jing, Y. and Zhao, Y., 2016a. Purification and antitumor activity in vitro of polysaccharides from Apostichopus japonicus spawn. Food Science 37: 105-110. http://www.spkx.net.cn/EN/10.7506/ spkx1002-6630-201623018

Liu, X.X., Hao, J.J., Shan, X.D., Zhang, X., Zhao, X.L., Li, Q.Y., Wang, X.J., Cai, C., Li, G.Y. and Yu, G.L., 2016b. Antithrombotic activities of fucosylated chondroitin sulfates and their depolymerized fragments from two sea cucumbers. Carbohydrate Polymers 152: 343-350. https://doi.org/10.1016/j. carbpol.2016.06.106

Liu, F., Sun, X., Zhu, W., Guo, Y., Liu, H.E., Yang, Z., Wang, Y., Wen, Y. and Wang, L., 2018. Establishment and determination of monosaccharide in sea cucumber. Progress in Fishery Sciences 39(2): 177-182. https://doi.org/10.19663/j. issn2095-9869.20170111001

Liu, X., Sun, Z.L., Zhang, M.S., Meng, X.M., Xia, X.K., Yuan, W.P., Xue, F. and Liu, C.H., 2012. Antioxidant and antihyperlipidemic activities of polysaccharides from sea cucumber Apostichopus japonicus. Carbohydrate Polymers 90: 1664-1670. https://doi. org/10.1016/j.carbpol.2012.07.047

Lu, Y. and Wang, B.L., 2009. The research progress of antitumorous effectiveness of Stichopus japonicus acid mucopolysaccharide in North of China. The American Journal of the Medical Sciences 337: 195-198. https://doi.org/10.1097/MAJ.0b013e318182ee45

Mathur, A., Hong, Y., Kemp, B.K., Barrientos, A.A. and Erusalimsky, J.D., 2000. Evaluation of fluorescent dyes for the detection of mitochondrial membrane potential changes in cultured cardiomyocytes. Cardiovascular Research 46: 126-138. https://doi.org/10.1016/S0008-6363(00)00002-X

Myron, P., Siddiquee, S. and Azad, S.A., 2017. Partial structural studies of fucosylated chondroitin sulfate (FuCS) using attenuated total reflection Fourier transform infrared spectroscopy (ATR-FTIR) and chemometrics. Vibrational Spectroscopy 89: 26-36. https://doi.org/10.1016/j.vibspec.2016.12.008

Pérez-Vega, J.A., Olivera-Castillo, L., Gómez-Ruiz, J.Á. and Hernández-Ledesma, B., 2013. Release of multifunctional peptides by gastrointestinal digestion of sea cucumber (Isostichopus badionotus). Journal of Functional Foods 5: 869-877. https:// doi.org/10.1016/j.jff.2013.01.036

Pollard, J., Rajabi-Siahboomi, A., Badhan, R.K.S., Mohammed, A.R. and Perrie, Y., 2019. High-throughput screening of excipients with a biological effect: a kinetic study on the effects of surfactants on efflux-mediated transport. Journal of Pharmacy and Pharmacology 71: 889-897. https://doi.org/10.1111/jphp.13072

Rajpurohit, R., Mansfield, K., Ohyama, K., Ewert, D. and Shapiro, I., 1999. Chondrocyte death is linked to development of a mitochondrial membrane permeability transition in the growth plate. Journal of Cellular Physiology 179: 287-296. https://doi.org/10.1002/(SICI)1097-4652(199906)179:3< 287::AID-JCP6>3.0.CO;2-T

Shin, G.-C., Kim, C., Lee, J.-M., Cho, W.-S., Lee, S.-G., Jeong, M., Cho, J. and Lee, K., 2009. Apigenin-induced apoptosis is mediated by reactive oxygen species and activation of ERK1/2 in rheumatoid fibroblast-like synoviocytes. ChemicoBiological Interactions 182: 29-36. https://doi.org/10.1016/j. cbi.2009.07.016

Siegel, R.L., Miller, K.D. and Jemal, A., 2016. Cancer statistics, 2016. CA: A Cancer Journal for Clinicians 66: 7-30. https://doi. org/10.3322/caac.21332

Sinha, K., Das, J., Pal, P.B. and Sil, P.C., 2013. Oxidative stress: the mitochondria-dependent and mitochondria-independent pathways of apoptosis. Archives of Toxicology 87: 1157-1180. https://doi.org/10.1007/s00204-013-1034-4

Song, S., Wu, S.F., Ai, C.Q., Xu, X., Zhu, Z.J., Cao, C.Y., Yang, J.F. and Wen, C.R., 2018. Compositional analysis of sulfated polysaccharides from sea cucumber (Stichopus japonicus) released by autolysis reaction. International Journal of Biological Macromolecules 114: 420-425. https://doi.org/10.1016/j. ijbiomac.2018.03.137

Sun, Y.J., Gong, G.P., Guo, Y.M., Wang, Z.F., Song, S., Zhu, B.W., Zhao, L.L. and Jiang, J.J., 2018. Purification, structural features and immunostimulatory activity of novel polysaccharides from Caulerpa lentillifera. International Journal of Biological Macromolecules 108: 314-323. https://doi.org/10.1016/j.ijbiomac.2017.12.016

Szeleszczuk, Ł., Pisklak, D.M., Zielińska-Pisklak, M. and Jurczak, E., 2019. A new polymorph of $17-\beta$-estradiol and the application of different analytical techniques (ssNMR, PXRD, DSC, and FTIR) for its study. Journal of Molecular Structure 1183: 274-280. https://doi.org/10.1016/j.molstruc.2019.01.102

Tang, Y.J., Zhao, H., Yao, J.H., Zhu, Z.H., Sun, D.H. and Zhang, M., 2019. A doxorubicin and vincristine drug release system based on magnetic PLGA microspheres prepared by 
coaxial electrospray. Journal of Materials Science 54: 9689-9706. https://doi.org/10.1007/s10853-019-03575-9

Thinh, P.D., Ly, B.M., Usoltseva, R.V., Shevchenko, N.M., Rasin, A.B., Anastyuk, S.D., Malyarenko, O.S., Zvyagintseva, T.N., San, P.T. and Ermakova, S.P., 2018. A novel sulfated fucan from Vietnamese sea cucumber Stichopus variegatus: isolation, structure and anticancer activity in vitro. International Journal of Biological Macromolecules 117: 1101-1109. https://doi. org/10.1016/j.ijbiomac.2018.06.017

Ustyuzhanina, N.E., Bilan, M.I., Dmitrenok, A.S., Borodina, E.Y., Stonik, V.A., Nifantiev, N.E. and Usov, A.I., 2017. A highly regular fucosylated chondroitin sulfate from the sea cucumber Massinium magnum: structure and effects on coagulation. Carbohydrate Polymers 167: 20-26. https://doi.org/10.1016/j. carbpol.2017.02.101

Vaikundamoorthy, R., Krishnamoorthy, V., Vilwanathan, R. and Rajendran, R., 2018. Structural characterization and anticancer activity (MCF7 and MDA-MB-231) of polysaccharides fractionated from brown seaweed Sargassum wightii. International Journal of Biological Macromolecules 111: 1229-1237. https:// doi.org/10.1016/j.ijbiomac.2018.01.125

Wu, F.J., Xue, Y., Tang, Q.J., Xu, J., Du, L., Xue, C.H., Takahashi, K. and Wang, Y.M., 2013. The protective effects of cerebrosides from sea cucumber and starfish on the oxidative damage in PC12 cells. Journal of Oleo Science 62: 717-727. https://doi. org/10.5650/jos.62.717

Xiong, Q.P., Song, Z.Y., Hu, W.H., Liang, J., Jing, Y., He, L., Huang, S., Wang, X.L., Hou, S.Z., Xu, T.T., Chen, J., Zhang, D.Y., Shi, Y.Y., Li, H.L. and Li, S.J., 2018. Methods of extraction, separation, purification, structural characterization for polysaccharides from aquatic animals and their major pharmacological activities. Critical Reviews in Food Science and Nutrition 60: 1-16. https://doi.org/10.1080/10408398.2018.1512472

Xu, D.X., Zhang, J.J., Cao, Y.P., Wang, J. and Xiao, J.S., 2016. Influence of microcrystalline cellulose on the microrheological property and freeze-thaw stability of soybean protein hydrolysate stabilized curcumin emulsion. LWT - Food Science and Technology 66: 590-597. https://doi.org/10.1016/j.lwt.2015.11.002

Yang, D., Lin, F., Huang, Y., Ye, J. and Xiao, M., 2019. Separation, purification, structural analysis and immune-enhancing activity of sulfated polysaccharide isolated from sea cucumber viscera. International Journal of Biological Macromolecules 155:10031018. https://doi.org/10.1016/j.ijbiomac.2019.11.064

Yang, W.J., Cai, Y., Yin, R.H., Lin, L.H., Li, Z.K., Wu, M.Y. and Zhao, J.H., 2018. Structural analysis and anticoagulant activities of two sulfated polysaccharides from the sea cucumber Holothuria coluber. International Journal of Biological Macromolecules 115: 1055-1062. https://doi.org/10.1016/j. ijbiomac.2018.04.175

Ye, L., Xu, L. and Li, J., 2012. Preparation and anticoagulant activity of a fucosylated polysaccharide sulfate from a sea cucumber Acaudina molpadioidea. Carbohydrate Polymers 87: 20522057. https://doi.org/10.1016/j.carbpol.2011.10.014
Yu, L., Xue, C.H., Chang, Y.G., Hu, Y.F., Xu, X.Q., Ge, L. and Liu, G.C., 2015. Structure and rheological characteristics of fucoidan from sea cucumber Apostichopus japonicus. Food Chemistry 180: 71-76. https://doi.org/10.1016/j.foodchem.2015.02.034

Yun, L.Y., Wu, T., Liu, R., Li, K. and Zhang, M., 2018. Structural variation and microrheological properties of a homogeneous polysaccharide from wheat germ. Journal of Agricultural and Food Chemistry 66: 2977-2987. https://doi.org/10.1021/acs. jafc.7b04730

Zhang, W., Lu, Y., Xu, B., Wu, J., Zhang, L., Gao, M., Zheng, S., Wang, A., Zhang, C., Chen, L. and Lei, N., 2009. Acidic mucopolysaccharide from Holothuria leucospilota has antitumor effect by inhibiting angiogenesis and tumor cell invasion in vivo and in vitro. Cancer Biology \& Therapy 8: 1489-1499. https://doi. org/10.4161/cbt.8.15.8948

Zhang, T.T., Xu, J., Wang, Y.M. and Xue, C.H., 2019. Health benefits of dietary marine DHA/EPA-enriched glycerophospholipids. Progress in Lipid Research 75: 100997. https://doi.org/10.1016/j. plipres.2019.100997

Zhang, B., Xue, C., Hu, X., Xu, J., Li, Z., Wang, J., Yanagita, T., Xue, Y. and Wang, Y., 2012. Dietary sea cucumber cerebroside alleviates orotic acid-induced excess hepatic adipopexis in rats. Lipids in Health and Disease 11: 48. https://doi. org/10.1186/1476-511X-11-48

Zhang, T.T., Yang, L. and Jiang, J.G., 2015a. Effects of thonningianin A in natural foods on apoptosis and cell cycle arrest of HepG-2 human hepatocellular carcinoma cells. Food \& Function 6: 2588-2597. https://doi.org/10.1039/C5FO00388A

Zhang, T.T., Yang, L. and Jiang, J.G., 2015b. Tormentic acid in foods exerts anti-proliferation efficacy through inducing apoptosis and cell cycle arrest. Journal of Functional Foods 19: 575-583. https://doi.org/10.1016/j.jff.2015.09.061

Zhao, Y.H., Li, B.F., Liu, Z.Y., Dong, S.Y., Zhao, X. and Zeng, M.Y., 2007. Antihypertensive effect and purification of an ACE inhibitory peptide from sea cucumber gelatin hydrolysate. Process Biochemistry 42: 1586-1591. https://doi.org/10.1016/j. procbio.2007.08.011

Zhao, Y.C., Xue, C.H., Zhang, T.T. and Wang, Y.M., 2018. Saponins from sea cucumber and their biological activities. Journal of Agricultural and Food Chemistry 66: 7222-7237. https://doi. org/10.1021/acs.jafc.8b01770

Zhou, X.Q., Wang, C.H. and Jiang, A.L., 2012. Antioxiant peptides isolated from sea cucumber Stichopus japonicus. European Food Research and Technology 234: 441-447. https://doi. org/10.1007/s00217-011-1610-x

Zhu, X., Wang, K., Zhang, K., Zhu, L. and Zhou, F., 2014. Ziyuglycoside II induces cell cycle arrest and apoptosis through activation of ROS/JNK pathway in human breast cancer cells. Toxicology Letters 227: 65-73. https://doi.org/10.1016/j. toxlet.2014.03.015 


\section{Supplementary information}

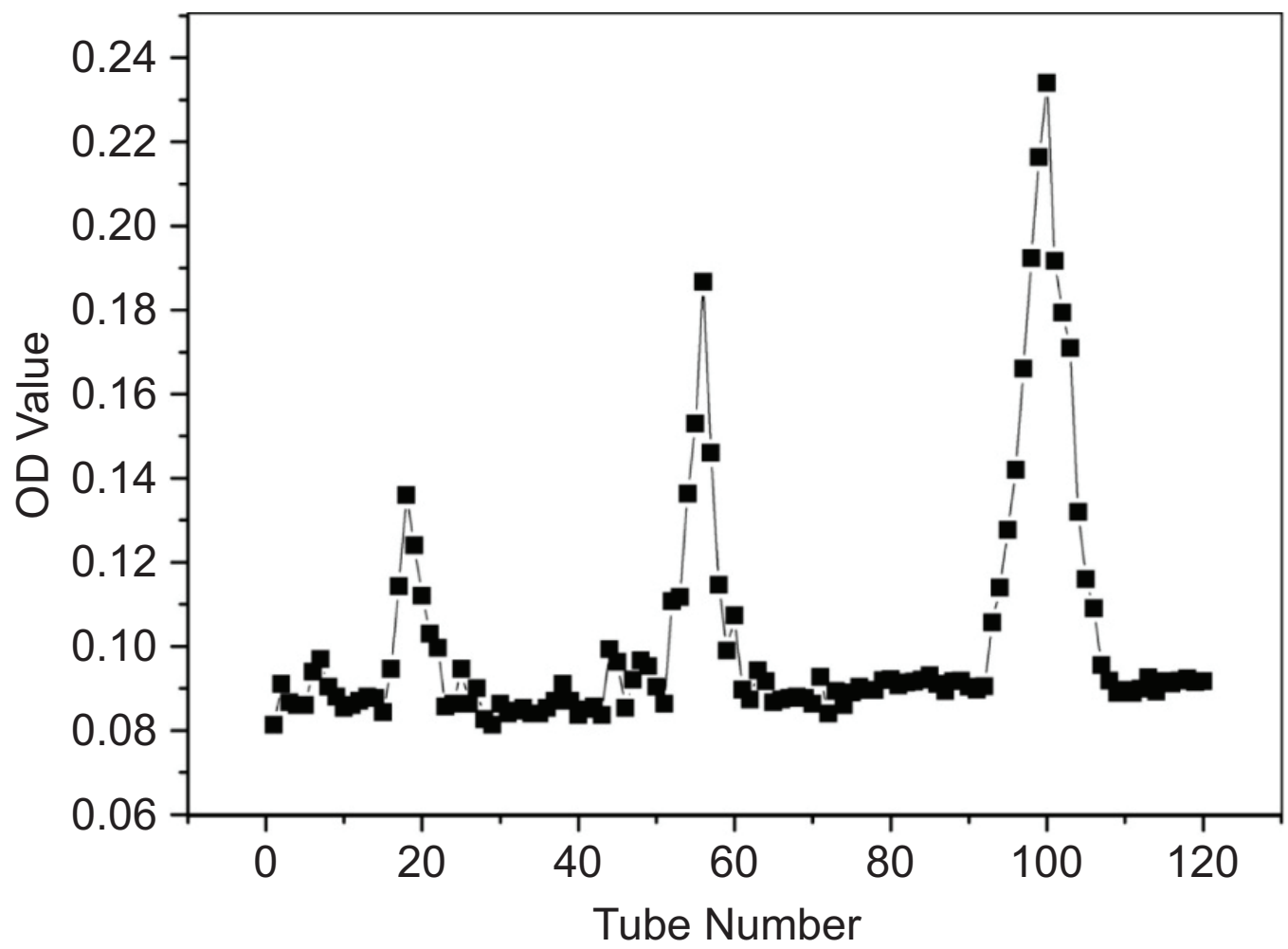

Figure S1. Elution profile of sea cucumber polysaccharides (SCP) in DEAE-52 column using distilled NaCl solution as eluent.

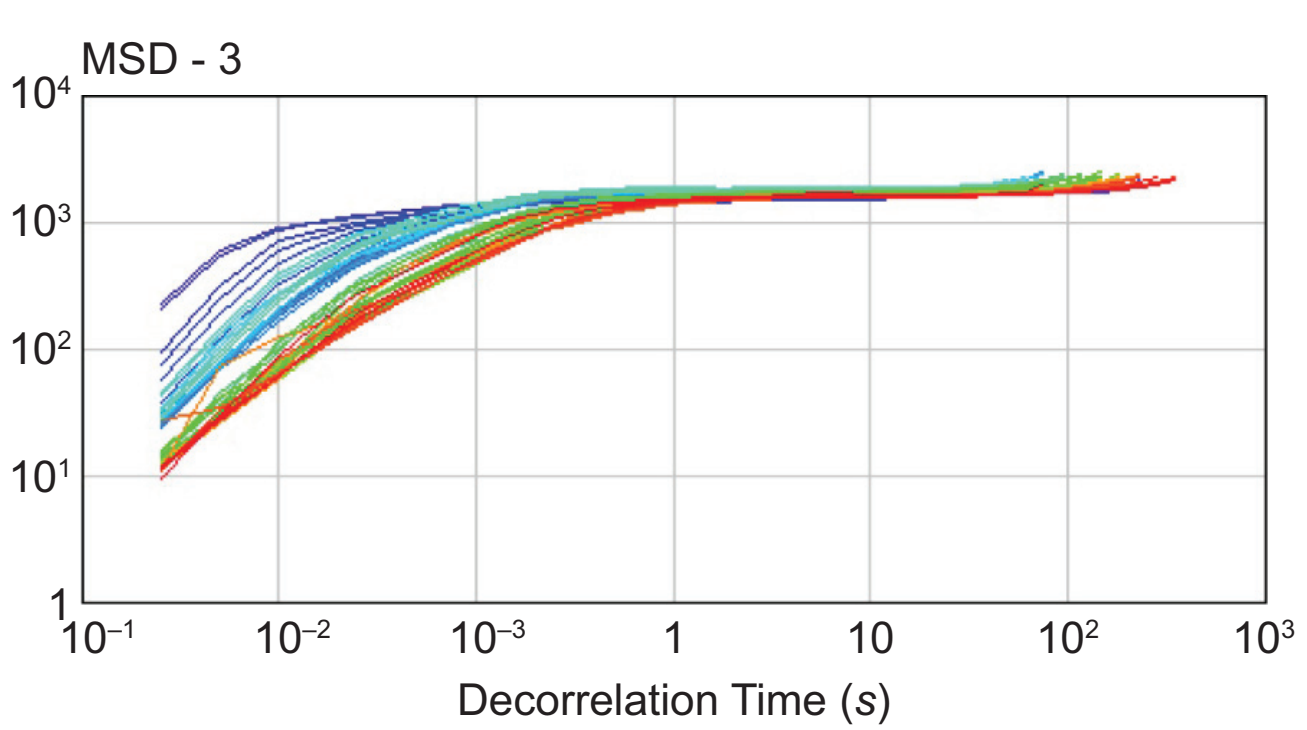

- $0 "$

- 7' 49"

- 13' 55"

- 20' 25"

$-26^{\prime} 38^{\prime \prime}$

$-32^{\prime} 17^{\prime \prime}$

- 40' 29"

$-47^{\prime} 20^{\prime \prime}$

-57 ' $12 "$

- 1h 11' $57^{\prime \prime}$

- 1h 27' $27^{\prime \prime}$

- 1h 45'38"

- 2h 8' 44"

$-2 \mathrm{~h} \mathrm{31'55"}$

Figure S2. MSD curve of $3 \mathrm{mg} / \mathrm{mL} \mathrm{SCP}$ solution. 


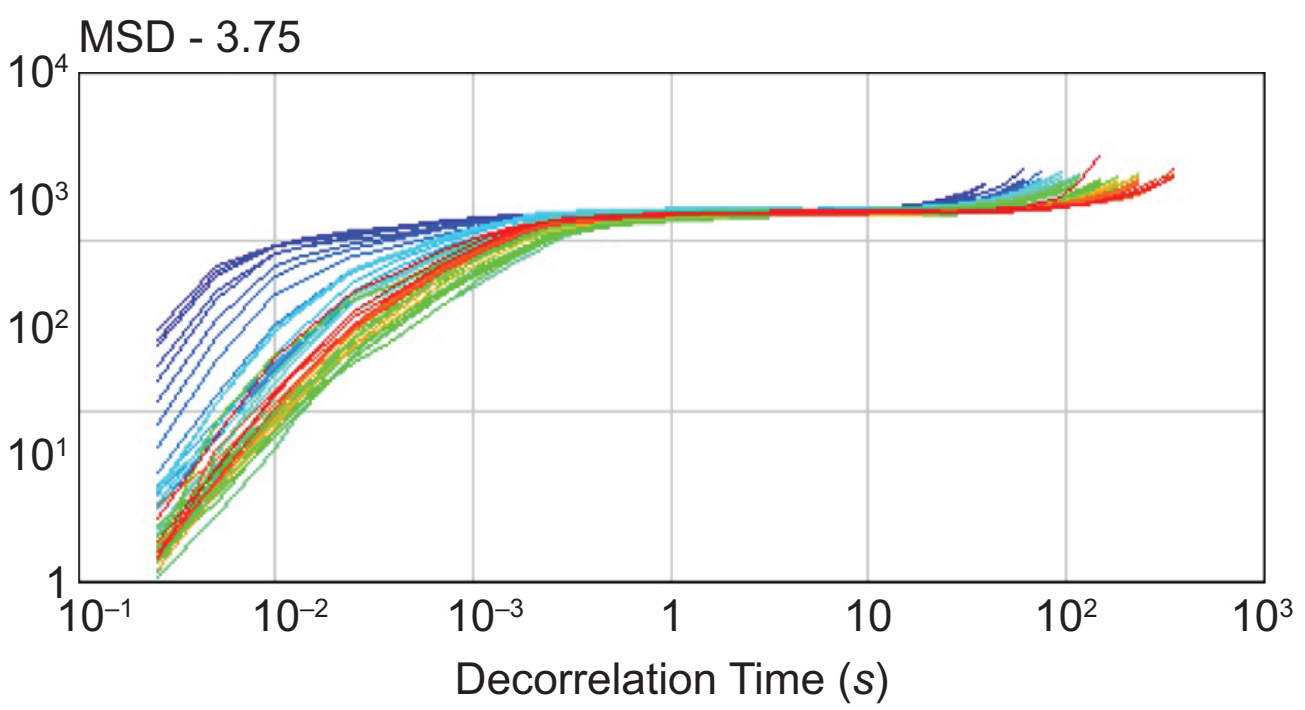

- 0 "

- 3' 19"

- 9' 1"

- 15' 48"

- 21'11"

- 29' 6"

- 38' 56"

- 45' 47"

- 57' 18"

- 1h 12' 38 "

- 1h 25'19"

- 1h 44'40"

- 2h 8' 29"

- 2h 31'57'

Figure S3. MSD curve of $3.75 \mathrm{mg} / \mathrm{mL}$ SCP solution.

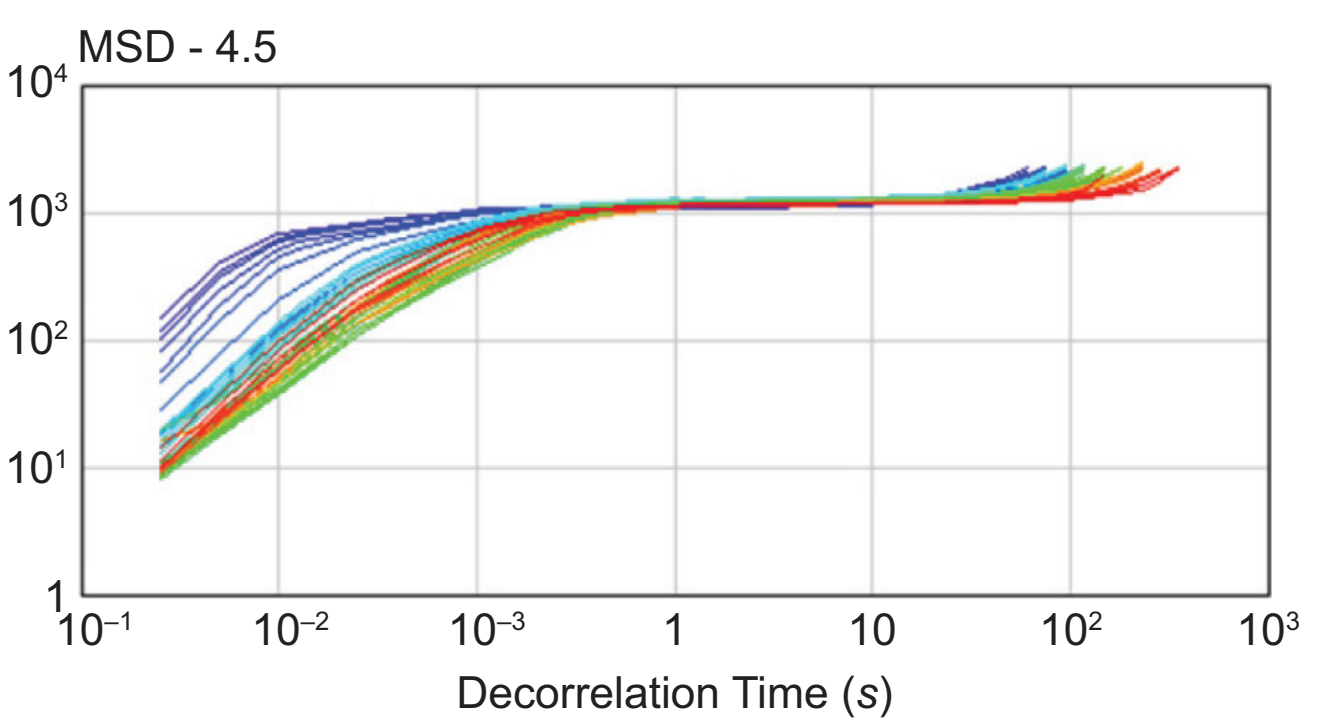

- $0 "$

- 4' 49"

- 10'32"

- 19' 17"

- 24' 33"

- 32' 14"

- 39' $26^{\prime \prime}$

- 50' 20"

- 59' $16^{\prime \prime}$

- 1h 12'45"

- 1h 25' 25"

- 1h 47'55"

- 2h 8' 0"

$-2 \mathrm{~h}$ 30'58"

Figure S4. MSD curve of $4.5 \mathrm{mg} / \mathrm{mL}$ SCP solution. 